Volume 9 Nomor 1 Tahun 2021

\title{
Penerapan Model Pembelajaran Creative Problem Solving Untuk Meningkatkan Kemampuan Pemecahan Masalah Soal Cerita Interpretasi Data
}

\section{Lucky Dwi Fitriani}

Universitas Sebelas Maret

luckydwifitriani@gmail.com

\section{Article History}

received 30/4/2021

\begin{abstract}
The research was based on the results of students ability to solve story problem that have not reached the minimum completeness criteria. The purpose of this research is to improve the problem solving ability of data interpreting story problem by applying the CPS learning model. This research is a classroom action research conducted in two cycles with planning, action, observation and reflection steps. The research subjects were 30 students of class V SDN Soropadan Surakarta. Data collection techniques used are observation, interviews, tests and documentation. The result of the first cycle of $50 \%$ classically and the second cycle of $83,33 \%$ classically. The conclusion is that the application of the CPS learning model can improve the problem solving ability of story problem in class V SDN Soropadan Surakarta in the 2020/2021 school year.
\end{abstract}

Keywords: Creative Problem Solving,Problem Solving Ability, Story Problem

\section{Abstrak}

Penelitian ini dilatarbelakangi hasil kemampuan menyelesaikan soal cerita peserta didik belum mencapai kriteria ketuntasan minimal. Tujuan penelitian ini adalah untuk meningkatkan kemampuan pemecahan masalah soal cerita interpretasi data dengan menerapkan model pembelajaran CPS. Penelitian ini merupakan penelitian tindakan kelas yang dilaksanakan dalam dua siklus dengan langkah perencanaan, tindakan, pengamatan dan refleksi. Subjek penelitian yaitu 30 peserta didik kelas V SDN Soropadan Surakarta. Teknik pengumpulan data yang digunakan yaitu observasi, wawancara, tes dan dokumentasi. Hasil siklus I sebesar $50 \%$ secara klasikal dan siklus II sebesar $83,33 \%$ secara klasikal. Kesimpulannya adalah penerapan model pembelajaran CPS dapat meningkatkan kemampuan pemecahan masalah soal cerita pada kelas V SDN Soropadan Surakarta tahun ajaran 2020/2021.

Kata kunci: Creative Problem Solving,Kemampuan Pemecahan Masalah, Soal Cerita 


\section{PENDAHULUAN}

Zaman telah menunjukkan perkembangan teknologi yang begitu cepat, oleh karena itu dibutuhkan keahlian berbagai macam bidang untuk menghadapi segala situasi. Fakta abad 21 memperlihatkan bahwa untuk menghadapi perkembangan teknologi dibutuhkan pemecahan masalah dalam kehidupan sehari-hari secara produktif. Pemecahan masalah merupakan kemahiran yang harus dimiliki setiap peserta didik. Bidang yang dapat mempengaruhi adanya kemahiran dalam menghadapi suatu permasalahan adalah pendidikan. Pendidikan sangat mempengaruhi terjadinya pola pikir saat memecahkan suatu masalah. Dalam ranah pendidikan, kemampuan pemecahan masalah terintegrasi dalam muatan pembelajaran matematika. Pembelajaran matematika dapat diawali dengan pengamatan, pertanyaan, percobaan, penalaran, penyajian dan penciptaan (Fuadi, 2016: 47-48).

Pemecahan masalah dalam matematika ada dua jenis, yaitu pemecahan masalah melalui proses dan pemecahan masalah dalam bentuk soal cerita (Shadiq, 2015: 110). Menyelesaikan masalah berbentuk soal cerita memiliki langkah-langkah penyelesaian. National Council of Teacher Mathematic menyatakan bahwa standar matematika meliputi 2 pembahasan, yaitu standar materi dan standar proses. Standar proses memiliki 5 komponen dan pemecahan masalah termasuk komponen tersebut. Salah satu contoh pemecahan masalah di Sekolah Dasar yaitu menyelesaikan soal cerita. Penyelesaian soal cerita memiliki 4 tahap, yaitu: (1) memahami uraian permasalahan, (2) Menyusun rencana penyelesaian masalah, (3) melaksanakan rencana penyelesaian masalah, (4) pengecekan proses, hasil dan penarikan kesimpulan (Rostika dan Junita, 2017). Pentingnya kemampuan menyelesaikan soal cerita diajarkan pada jenjang Sekolah Dasar yaitu untuk melatih peserta didik dapat memecahkan permasalahan yang ditemui dalam kehidupan sehari-hari.

Merujuk hasil pengamatan beserta tanya jawab terhadap wali kelas V SDN Soropadan Surakarta pada tanggal 1 Maret 2021. Diperoleh informasi bahwa: 1) nilai matematika lebih rendah dibandingkan nilai muatan pelajaran lainnya; 2) pelajaran matematika dianggap sulit dipahami oleh peserta didik; 3) adanya kesenjangan kemampuan antar peserta didik; 4) penyelesaian soal cerita matematika yang rumit membuat peserta didik tidak tertarik untuk belajar matematika. Diperkuat hasil tes pratindakan yang dilakukan pada tanggal 9 Maret 2021, diperolehan data hasil tes pratindakan tertulis $20 \%$ atau hanya 6 dari 30 peserta didik bisa memenuhi KKM $\geq 75$. Adapun sebanyak 24 peserta didik (80\%) belum mampu memenuhi KKM $\geq 75$. Nilai rata-rata kelas juga di bawah KKM yaitu 47,9. Ditinjau dari hasil nilai pratindakan dapat dikatakan bahwa kemampuan pemecahan masalah soal cerita interpretasi data terkategorikan rendah sehingga perlu dilakukan tindakan perbaikan.

Permasalahan rendahnya kemampuan pemecahan masalah pernah diatasi oleh Purnamasari (2016) yang berjudul Penerapan Model CPS terhadap Self Concept dan Kemampuan Memecahkan Masalah Peserta Didik Kelas V. Penelitian selanjutnya dilakukan oleh Dian Veramita \& Mulyono (2018) dalam penelitiannya menerapkan model pembelajaran kooperatif tipe TTW untuk meningkatkan keterampilan memecahkan masalah matematika. Penelitian selanjutnya dilakukan oleh KashaniVahid et al., (2017) dalam jurnal Thinking Skills and Creativity, yang berjudul "Can a Creative Interpersonal Problem Solving Program Improve Creative Thinking in Gifted Elementary Students?. Relevansi antara penelitian ini yaitu dengan menerapkan model pembelajaran CPS untuk meningkatkan kemampuan pemecahan masalah secara kreatif pada peserta didik SD.

Berdasarkan paparan di atas, kemampuan pemecahan masalah dapat diatasi dengan menerapkan inovasi pembelajaran seperti menerapkan model pembelajaran yang sesuai dengan permasalahan yang sedang dihadapi. Salah satu model pembelajaran pemecahan masalah yaitu Creative Problem Solving (CPS). Model pembelajaran CPS menekankan pada penemuan-penemuan ide kreatif untuk mencari 
penyelesaian masalah yang paling efisien dan efektif dengan menggunakan proses berpikir divergen dan konvergen (Isrok'atun \& Rosmala, 2018: 149). Huda (2013:298) menyatakan bahwa model pembelajaran CPS memiliki tahapan-tahapan yang harus dilakukan, yaitu: 1) Objective Finding, 2) Fact Finding, 3) Problem Finding, 4) Idea Finding, 5) Solution Finding, 6) Acceptance Finding.

Berdasarkan latar belakang yang telah diuraikan di atas, maka rumusan masalah yang dapat diajukan yaitu: apakah penerapan model pembelajaran Creative Problem Solving (CPS) dapat meningkatkan kemampuan pemecahan masalah soal cerita interpretasi data pada peserta didik kelas $\mathrm{V}$. Rumusan ini mendasari tujuan dilakukannya tindakan yaitu untuk meningkatkan kemampuan pemecahan masalah soal cerita interpretasi data pada peserta didik kelas V SDN Soropadan Surakarta tahun ajaran 2020/2021.

\section{METODE}

Metode yang digunakan yaitu Penelitian Tindakan Kelas yang dilaksanakan sebanyak 2 siklus. Setiap siklus memiliki 4 tahap, yaitu 1) perencanaan, 2) tindakan, 3) pengamatan, dan 4) refleksi. Penelitian dilaksanakan di SDN Soropadan Surakarta yang beralamatkan di jalan Srilesyo No. 08 Rt 01 Rw IV Karangasem, Laweyan Surakarta. Subjek penelitian adalah guru dan peserta didik kelas $\mathrm{V}$ yang berjumlah 30 orang dengan jumlah laki-laki 13 dan jumlah perempuan 17. Teknik pengumpulan data yang digunakan yaitu observasi, wawancara, tes dan dokumentasi. Data hasil penelitian berupa data kuantitatif bersumber dari perolehan hasil tes kemampuan menyelesaikan soal cerita interpretasi data. Uji validitas data menggunakan triangulasi sumber dan triangulasi teknik. Miles dan Huberman dalam Sugiyono (2015:337) menyatakan bahwa terdapat 4 komponen dalam analisis data, yaitu: 1) data collection, 2) data reduction, 3) data display, 4) verification.

Instrumen penilaian dimodifikasi dari sintaks pemecahan masalah karangan Polya. Penentuan ketuntasan penelitian menggunakan KKM $\geq 75$. Indikator keberhasilan penelitian yaitu $80 \%$ (24 dari 30 peserta didik mencapai nilai KKM $\geq 75$ ). Ketika peserta didik mampu memperoleh nilai $\geq 75$, maka dikatakan mampu menyelesaikan soal cerita interpretasi data. Jadi, jika $80 \%$ dari jumlah peserta didik tuntas mencapai KKM $\geq 75$, maka penerapan model CPS berhasil meningkatkan kemampuan pemecahan masalah soal cerita interpretasi data.

HASIL DAN PEMBAHASAN

Hasil evaluasi kemampuan pemecahan masalah soal cerita peserta didik kelas $\mathrm{V}$ SDN Soropadan Surakarta pada pratindakan, siklus I dan siklus II mengalami peningkatan. Peningkatan tersebut dapat dilihat dari tabel dan diagram berikut.

Tabel 1. Perbandingan Nilai Kemampuan Pemecahan Masalah Soal Cerita Interpretasi Data Pratindakan, Siklus I dan Siklus II

\begin{tabular}{llccc}
\hline No. & \multicolumn{1}{c}{ Keterangan } & Pratindakan & Siklus I & Siklus II \\
\hline 1. & Nilai Rata-rata & 46,7 & 66,58 & 82,57 \\
2. & Ketuntasan klasikal & $20 \%$ & $50 \%$ & $83,33 \%$ \\
3. & Nilai Tertinggi & 82 & 81,5 & 92 \\
4. & Nilai Terendah & 4 & 32 & 66,5 \\
\hline
\end{tabular}




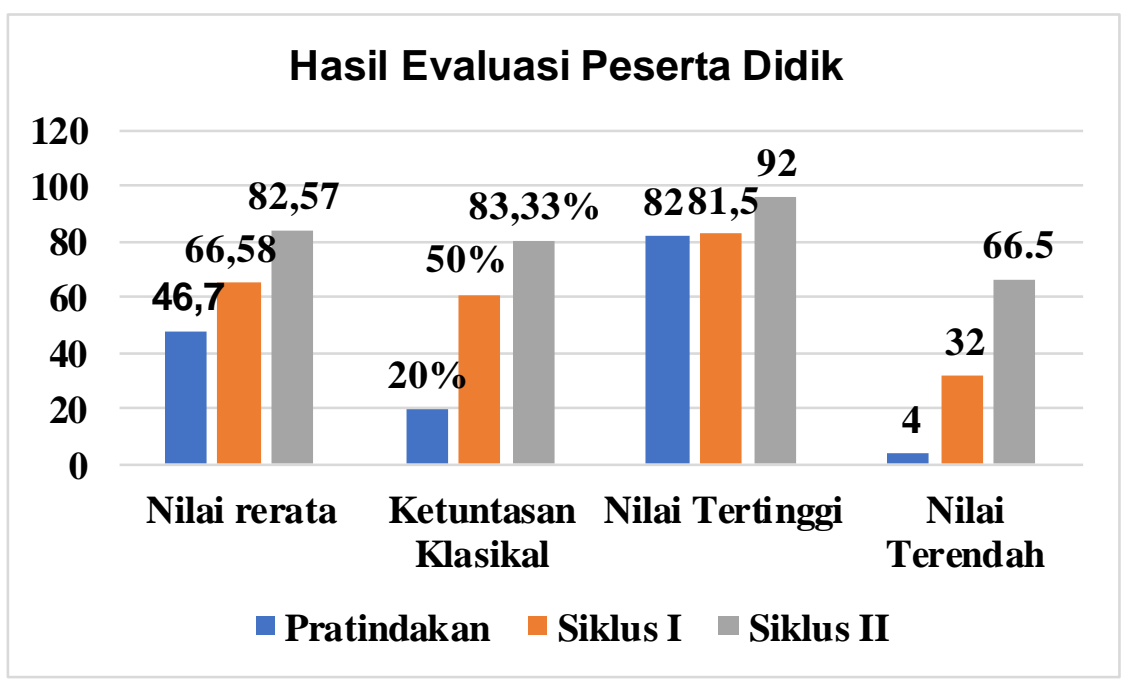

\section{Gambar 1. Hasil Evaluasi Peserta Didik Pratindakan, Siklus I dan II}

Tabel 1 mendeskripsikan perbandingan hasil kemampuan pemecahan masalah soal cerita interpretasi data pada pratindakan, siklus I dan siklus II. Hasil pratindakan menunjukkan persentase ketuntasan klasikal masih rendah yaitu 20\% (6 dari 30 peserta didik) mencapai $\mathrm{KKM} \geq 75$ dengan nilai rata-rata 46,7. Merujuk hasil pratindakan, maka dilakukan perbaikan yang berguna untuk meningkatkan kemampuan pemecahan masalah soal cerita interpretasi data melalui penerapan model pembelajaran CPS.

Pada siklus I mengalami kenaikan dibandingkan dengan pratindakan. Perolehan persentase ketuntasan klasikal pada siklus I sebesar 50\% (15 dari 30 peserta didik) tuntas dengan nilai rata-rata 66,58. Perolehan persentase ketuntasan klasikal pada siklus I belum mencapai target kinerja penelitian yaitu $80 \%$, sehingga perlu dilakukan siklus lanjutan yaitu siklus II. Pada siklus II persentase ketuntasan klasikal naik menjadi 83,33\% (25 dari 30 peserta didik) berhasil mencapai KKM dengan nilai rata-rata kelas 82,57. Perolehan persentase ketuntasan klasikal pada siklus II telah memenuhi target kinerja penelitian. Peningkatan terjadi dikarenakan penerapan model pembelajaran CPS dilakukan secara maksimal.

Model CPS dinyatakan dapat meningkatkan kemampuan pemecahan masalah soal cerita interpretasi data kelas V SDN Soropadan Surakarta. Hal itu dibuktikan dari hasil tes pratindakan hingga siklus II yang terus mengalami peningkatan. Pembelajaran dengan menerapkan model pembelajaran CPS dapat meningkatkan antusias dan semangat peserta didik pada saat mengikuti pembelajaran matematika. Peserta didik mulai percaya dengan kemampuan yang mereka miliki dan dapat mengoptimalkan kualitas pembelajaran dengan lebih aktif dan percaya diri.

Penelitian ini diperkuat dengan penelitian terdahulu yang dilakukan oleh Purnamasari (2016) yang menyatakan bahwa model pembelajaran CPS mampu meningkatkan kemampuan pemecahan masalah dan Self Concept pada peserta didik kelas $\mathrm{V}$ dengan nilai rata-rata mencapai 87,36 . Selanjutnya penilitian yang dilakukan oleh Dian Veramita \& Mulyono (2018) yang menunjukkan ketuntasan pemecahan masalah soal cerita dari $22,5 \%$ kondisi awal naik menjadi $67,5 \%$ pada siklus I dan kembali naik menjadi $90 \%$ pada siklus II. 


\section{SIMPULAN}

Berdasarkan uraian hasil dan pembahasan yang telah dipaparkan, dapat disimpulkan bahwa penerapan model pembelajaran CPS dapat meningkatkan kemampuan pemecahan masalah soal cerita pada peserta didik kelas V SDN Soropadan Surakarta tahun ajaran 2020/2021. Peningkatan tersebut didukung dengan adanya peningkatan pada keempat aspek penyelesaian soal cerita. Adapun keempat aspek tersebut yaitu: 1) memahami uraian permasalahan, 2) menyusun rencana penyelesaian masalah, 3) melaksanakan rencana penyelesaian masalah, 4) pengecekan proses, hasil dan penarikan kesimpulan. Selain adanya peningkatan keempat aspek penyelesaian soal cerita, hasil tes kemampuan pemecahan maslah soal cerita juga meningkat. Peningkatan tersebut dibuktikan dari ketercapaian persentase ketuntasan klasikal pada pratindakan 20\%, hasil persentase tersebut meningkat pada siklus I menjadi $50 \%$ dan kembali meningkat pada siklus II menjadi $83,33 \%$. Peningkatan persentase ketuntasan klasikal tersebut terjadi karena penerapan langkah-langkah model pembelajaran CPS yang dilakukan selama penelitian sesuai dengan prosedur model pembelajaran CPS dengan dimodifikasi menyesuaikan kondisi penelitian.

\section{DAFTAR PUSTAKA}

Dian Veramita, I., \& Mulyono, H. (2018). Improving Mathematical Problem Solving Skill Through The Application Cooperative Learning Model of Think Talk Write (TTW) Type in Student Grade V Elementary School (Classroom Action Research on Grade V Students of SD N Pajang 2 No. 171 Surakarta 2017/2018,1(1), 360366.

Fuadi, dkk. 2016. Peningkatan Kemampuan Pemahaman dan Pemahaman Matematis melalui Pendekatan Kontekstual. Jurnal Didakti Matematika, Vol 3. No 1. hal 4748.

Huda, M. (2015). Model-model Pembelajaran dan Pembelajaran. Yogyakarta: Pustaka Pelajar

Isrok'atun, \& Rosmala. (2018). Model-Model Pembelajaran Matematika. Jakarta: Bumi Aksara.

Kashani-Vahid, L., Afrooz, G. A., Shokoohi-Yekta, M., Kharrazi, K., \& Ghobari, B. (2017). Can a creative interpersonal problem solving program improve creative thinking in gifted elementary students? Thinking Skills and Creativity, 24, 175185.

NCTM 2000 Principles and Standards for School Mathematics

Purnamasari, V. (2016). Penerapan Model Creative Problem Solving (CPS) Terhadap Self Concept dan Kemampuan Memecahkan Masalah Siswa Kelas V, 3(3), 5664.

Rostika, D., \& Junita, H. (2017). Peningkatan Kemampuan Pemecahan MAsalah Siswa SD dalam Pembelajaran Matematika Dengan Model Diskursus Multy Representation (DMR). EduHumaniora, 9(1), 35-46.

Shadiq, F. (2014). Pembelajaran Matematika; Cara Meningkatkan Kemampuan Berpikir Siswa. Yogyakarta: Graha IImu.

Sugiyono. (2015). Metode Penelitian Pendidikan. Bandung: Alfabeta 